\title{
Configurações
}

Revista Ciências Sociais

$26 \mid 2020$

Economy and Society: politics, practices, agents, and institutions

\section{"Very Dull \& No Business Doing": A Reassessment of the American Sandalwood Trade between Hawaii and China, 1790-1832}

"Muito aborrecido e um negócio que nunca deveria ter sido feito": uma reavaliação do comércio americano de sândalo entre o Havaí e a China, 1790-1832

«Très ennuyeux \& sans affaires à faire»: une réévaluation du commerce américain de bois de santal entre Hawaï et la Chine, 1790-1832

\section{Eric Oakley}

\section{(2) OpenEdition}

\section{Journals}

Edição electrónica

URL: http://journals.openedition.org/configuracoes/10036

DOI: $10.4000 /$ configuracoes. 10036

ISSN: 2182-7419

Editora

Centro de Investigação em Ciências Sociais

Edição impressa

Paginação: 63-81

ISSN: 1646-5075

Refêrencia eletrónica

Eric Oakley, «"Very Dull \& No Business Doing": A Reassessment of the American Sandalwood Trade between Hawaii and China, 1790-1832 », Configurações [Online], 26 | 2020, posto online no dia 15 dezembro 2020, consultado o 21 dezembro 2020. URL : http://journals.openedition.org/ configuracoes/10036; DOI : https://doi.org/10.4000/configuracoes.10036 
Oakley, Eric - "Very Dull \& No Business Doing”: A Reassessment of the American Sandalwood Trade between Hawaii and China, 1790-1832. Configurações, vol. 26, 2020, pp. 63-81.

\title{
"Very Dull \& No Business Doing": A Reassessment of the American Sandalwood Trade between Hawaii and China, 1790-1832
}

ERIC OAKLEY*

Kennesaw State University

\begin{abstract}
This article is a critical reassessment of American trade in sandalwood between Hawaii and China from 1790-1832. It makes three contributions to the historiography of early commerce in the Pacific. First, it argues that American navigators did experiments with sandalwood throughout the 1790s. Second, it presents a price history that corroborates the influence of geopolitics upon the development of the sandalwood trade. Third, it demonstrates that a combination of deforestation, competition, and market saturation contributed to the decline of the trade in the 1820s.
\end{abstract}

Keywords: sandalwood, maritime, american, Hawaii, China trade.

\section{Resumo}

"Muito aborrecido e um negócio que nunca deveria ter sido feito": uma reavaliação do comércio americano de sândalo entre o Havaí e a China, 1790-1832

Este artigo é uma reavaliação crítica do comércio americano de sândalo entre o Havai e a China entre 1790 e 1832. Faz três contribuições para a historiografia do comércio inicial no Pacífico. Primeiro, argumenta que os navegadores americanos fizeram experiências com o sândalo ao longo da década de 1790. Segundo, apresenta um histórico de preços que corrobora a influência da geopolítica no desenvolvimento do comércio de sândalo. Terceiro, demonstra que uma combinação de desflorestação, competição e saturação do mercado contribuiu para o declínio do comércio na década de 1820.

Palavras-chave: sândalo, marítimo, americano, Havai, comércio da China.

*E-mail: eric.oakley@kennesaw.edu 
Résumé

«Très ennuyeux \& sans affaires à faire»: une réévaluation du commerce américain de bois de santal entre Hawaï et la Chine, 1790-1832

Cet article est une réévaluation critique du commerce américain de bois de santal entre Hawaï et la Chine entre 1790 et 1832. II apporte trois contributions à l'historiographie des premiers échanges commerciaux dans le Pacifique. Tout d'abord, il soutient que les navigateurs américains ont expérimenté le bois de santal tout au long des années 1790. Ensuite, il présente une histoire des prix qui corrobore l'influence de la géopolitique dans le développement du commerce du bois de santal. Pour finir, il prouve qu'une combinaison de déforestation, de concurrence et de saturation du marché a contribué au déclin de ce commerce dans les années 1820 .

Keywords: bois de santal, maritime, américains, Hawaï, commerce de la Chine.

\section{Introduction}

In May 1823, Charles Hammatt, commercial agent for the Bostonian firm of Bryant \& Sturgis, disembarked at Honolulu. The Hawaiian Islands were beautiful, no doubt, but other considerations weighed on his mind. William Heath Davis, a legendary sandalwood trader, had died. Moreover, the sandalwood trade itself seemed to have imploded over the previous eighteen months. In July, after a fruitless struggle to recover debts and revive the sandalwood trade, Hammatt remarked that Honolulu "is very dull \& no business doing." He resolved "to send the ship on a cruise around the islands, with the possibility of collecting some wood" but confided that "my expectations are not great." In August, when the vessel returned to Honolulu, he concluded that "the Ship has done much as I expected, tho' that is very little" (Hammatt, 1999: 6-7, 20-21).

The American sandalwood trade began as an outgrowth of the more extensive transpacific fur trade between Northwestern America and China. Companions of Captain Cook first discovered that otter skins "which did not cost the purchaser six-pence sterling sold in China for 100 dollars," an astronomical profit margin (Ledyard, 1783: 69-70). British captains pioneered the maritime fur trade in the 1780 s, often punctuating the long voyage with a replenishment stop in the Hawaiian Islands. In 1788, Columbia and Lady Washington, Bostonian fur-trading ships, became the first American vessels to cruise the Pacific. From the beginning, Americans looked for other branches of commerce to offset the unpredictable market in furs. Hawaiian sandalwood was the first such opportunity.

Sandalwood, genus Santalum, is an aromatic hardwood native to the tropics. One of the most valuable commercial tree species, sandalwood contains the compound santalol $\left(\mathrm{C}_{15} \mathrm{H}_{24} \mathrm{O}\right)$ which emits a "sweet, fragrant, persistent aroma" 
(Subasinghe, 2013: 1). Four species, out of sixteen worldwide, are endemic to the Hawaiian Islands. Sandalwood ('iliahi) was traditionally used as ritual firewood, as well as in the making of medicines, perfume, and musical instruments. In China, sandalwood (tanxiang, 檀香) was used in the manufacture of drugs, cosmetics, incense, furniture, and funeral pyres (Merlin and VanRavenswaay, 1990: 50). Sometime around 1790, American navigators began an experimental trade in sandalwood between producers in Hawaii and consumers in China.

The sandalwood trade suffered from a paradoxical fate-becoming commercially viable, only to collapse a few years later. How did this happen? The historiography of the Pacific sandalwood trade is thin. The sole monograph concerning this fascinating subject is Dorothy Shineberg's They Came for Sandalwood: A Study of the Sandalwood Trade in the South Pacific, 1830-1865 (1967). Nonetheless, Shineberg concentrates upon later developments in Melanesia rather than upon the Hawaiian origins of the business. "The Sandalwood Trade of Early Hawaii" offers a retrospective view of the sandalwood trade, albeit in a journalistic form suitable for Thrum's Hawaiian Almanac (1904). More recently, scientists and historians published a collection of articles as the Proceedings of the Symposium on Sandalwood in the Pacific (1990). Sandalwood also assumed a central place in Paul Fontenoy's short article "Ginseng, Otter Skins, and Sandalwood: The Conundrum of the China Trade" (1997). James Gibson gave a shorter treatment of its significance as an outgrowth of the maritime fur trade in Otter Skins, Boston Ships, and China Goods (1992). James Fichter's So Great a Proffit (2010) situated the sandalwood trade among various U.S. industries that undermined the commercial muscle of the British East India Company. Despite occasional appearances in the historiography of the Pacific World, however, no full treatment of the American trade in Hawaiian sandalwood exists.

This essay offers a critical reassessment of the American sandalwood trade, and it makes three contributions to the commercial historiography of the Pacific World. First, I contend that consistent experimentation with sandalwood began a decade earlier than is commonly recognized. In contrast to writers who deemed the origins of the trade to be "unknown," documentary evidence suggests that American captains tested the commodity throughout the 1790s (Thrum, 1904: 48). Second, I present the first price history for sandalwood imports at Canton, in China. Quantitative analysis enables us to corroborate or discern the impact of geopolitical events (embargos, piracy, and conflicts) upon the development of a reliable, profitable trade. Third, I argue that the collapse of the sandalwood trade from 1822-32 resulted from more than a glut of "inferior" produce on the market. In fact, the decline of sandalwood must be attributed to a constellation of factors including deforestation, competition, and market saturation. These conclusions contribute to our understanding of sandalwood as a business that helped to bridge the U.S. transition from the maritime fur trade to more permanent models of shipping 
in the Pacific. I emphasize that the conclusions in this article are tentative, and that further research on the subject is warranted.

\section{Revisiting the early sandalwood trade}

The documentary record strongly indicates that the sandalwood trade began around 1790. Joseph Felgelson, a forester, incorrectly claimed that "Sandalwood has been of historical importance since it was first exported in 1778" (Felgelson, 1990: 42). There is no evidence, however, that Cook's companions collected Hawaiian sandalwood or recognized its commercial value. King Kalakaua recounted a legend that "in 1787 several trading vessels visited the group, and the natives began to barter provisions and sandal-wood for firearms and other weapons of metal." This chronology, presented as an example of "fabulous folklore," may represent the conflation of multiple events (Kalakaua, 1888: 26-27). In 1788, William Douglas, a British captain, received instructions to reconnoiter the North Pacific and "lade on board as much as you can... of sandel-wood" (Meares, 1791, Il: appendix). In 1790, he stationed two crewmembers at Maui to collect 'iliahi, but their mission failed when the local ruler "threw off his protection" of them (Ingraham, 1971: 78, 82-83). It is also possible that Douglas shipped an "inferior quality" of wood, and there is no indication that he made a second attempt (Gibson, 1992: 254). Amaso Delano, an American captain, claimed that "as long ago as the year 1790, I saw more than thirty tons of what was called sandal wood brought from these islands to Canton" (Delano, 1817: 399). The precision of that date is questionable, but 1790 also approximates several events surrounding John Kendrick, the first American to navigate the Pacific Ocean.

One tradition suggests that Kendrick, commander of the Columbia expedition, pioneered the sandalwood trade between the Hawaiian Islands and China. In fact, Kendrick's appropriation of the brig Lady Washington may have necessitated an experiment in sandalwood. His decision to "take the Brig on my own account... and abide by all losses and gains" divided the expedition and left him in desperate need of operating funds (Howay, 1941: 471). Kendrick's subsequent activities have proven difficult to reconstruct, but he is documented to have replenished at the Hawaiian Islands in 1789 (Howay, 1928: 37). Tradition holds that his discovery of "iliahi was "accidental" and arising "in the purchase of firewood" (Thrum, 1904: 48). Ralph Kuykendall concluded that "it is altogether probable that sticks of this fragrant wood were included in batches of firewood delivered to trading ships and that its existence on the islands was discovered by the traders in this way" (Kuykendall, 1934; 370). The tale may be apocryphal, or even the inspiration for a later legend that John Jacob Astor "enjoyed a monopoly" on Santalum after one of his captains purchased it as fuel. (BHS, 1929: 15). George Vancouver reported that, in 1791, Kendrick left three crewmembers in the islands "for the purpose of collecting sandal-wood, and pearls" (Vancouver, 1798, I: 172). 
New evidence - albeit of a circumstantial nature-also suggests that Kendrick received market intelligence from his colleagues aboard Columbia. Captain Robert Gray documented the price of four grades of sandalwood at Canton. Gray observed that "Sandall Wood, first sort" sold at an astonishing \$55 dollars per picul. Even third-rate varieties fetched an appealing sum of $\$ 28$ (Columbia Papers I, 1787-1793). He also corresponded with Kendrick during his reconnaissance of the Hawaiian Islands. Gray made no mention of sandalwood, but he reported that the inhabitants of Niihau had few "curiosities" to trade because William Douglas-a rival sandalwood captain - had already "drained them of those articles." Could this be an oblique reference to 'iliahi, an untested commodity? Gray deposited a second letter (now lost, contents unknown) at Kauai-an island Kendrick later targeted for sandalwood (Nokes, 1991: 285). Moreover, Columbia's carpenter remained on the "big island" of Hawaii. Historians have described Isaac Ridler as a "deserter," but the evidence does not support this characterization. Ridler's expertise in the processing of wood suggests that he remained in the archipelago as a purchasing agent for Kendrick (Bradley, 1939: 286; Ingraham, 1972: 78).

The following decades, 1790-1810, probably saw greater experimentation with sandalwood than prior historians have recognized. Kuykendall believed that "the sandalwood trade of Hawaii was not of a great importance much before 1810," although he affirmed that "the wood was being exported in a small way for several years prior to that date" (Kuykendall, 1934: 370). Harold St. John couched the trade in purely hypothetical terms, arguing that "from 1790 to 1810 sandalwood may have been exported, but if so, in very small quantity, for little record is found" (St. John, 1947: 6). Prior historians were correct in their assessment that 'iliahi is poorly attested in sources from 1792-1804. However, one must read between the lines in cases where multiple societies, languages, and cultural traditions are at play. Delano remarked, in the context of expeditions between 1801 and 1806, that Americans discovered "within the past seven or eight years a considerable quantity of sandal-wood, and... made large profits by the traffic". If true, his statement indicates the establishment of a viable trade sometime between 1794 and 1799 (Delano, 1817: 399).

The prevailing historiographical attitude toward sandalwood is best illustrated in the editorial notes to Joseph Ingraham's Journal of the Brigantine Hope. In 1791, Ingraham learned that American vessels were "taking in sandalwood" and that islanders even used the commodity as bait in their attempt to capture the brig Eleanora. Ingraham did not question the ruse-he regarded sandalwood as an element of "trading as usual." Robert Kaplanoff, a modern editor, dismissed the account as an "error about the Eleanora's business" and suggested that "apparently, she was only taking on firewood." His conclusion is problematic in several ways. Ingraham received the report from a professional who understood the status of sandalwood: the carpenter, Isaac Ridler (Ingraham, 1972: 79). Other navigators heard similar accounts from individuals associated with Eleanor (Boit, 1981: 73). 
Material culture reinforces the reliability of the source. Hawaiians did differentiate between mundane wood and 'la'au 'ala, or aromatic wood, but both could be considered "firewood" (Merlin and VanRavenswaay, 1990: 49-50). Traders may have used the term interchangeably in the context of a commercial pidgin later known as "Sandalwood English" (Drechsel, 2014: 7-11).

The early absence of sources concerning sandalwood is frequently taken as confirmation that the initial cargo represented "an inferior kind... and the Chinese would not give anything for it" (Delano, 1817: 399). This much could be true. Outsiders could easily mistake naio or "false sandalwood," another aromatic hardwood, for the real item (Malo, 1898: 42; USDA, 1989: 4). Vancouver inspected a specimen but explained that it "seemed but lightly to answer the description given of the yellow sandal wood of India" and that his expedition was "not able... to determine its particular class or species" (Vancouver, 1798, I: 189). A botanical error could explain the failure of a cargo or two. It strains credulity, though, to suggest that traders shipped the wrong species for more than a decade. Published narratives of scientific navigation offered ample knowledge concerning the natural wealth of the Pacific World. Santalum appeared in references to a hardwood "which is burnt for people of distinction," a species resembling "mahogany," and "shrubs... used as a perfume in the east" (Bougainville, 1772: 269; Quimper, 1791: 36; Flinders, 1814, II: 171). Time was money, and most fur traders made frequent visits to the islands. Those returning from Canton could identify "true" sandalwood on sight (Perkins, 1856: 41). If John Kendrick failed to acquire true 'iliahi during his 1789 visit, or even in 1791, we cannot doubt he attempted to upon returning in 1793. In short, the botanical error was easy to correct.

How can we explain the documentary silence concerning sandalwood during a period of clear experimentation in the commodity? The best explanation is that sandalwood did not become a significant cargo item until 1804-05. American traders could not be considered "sandalwooders" prior to this period, as "iliahi remained secondary to their main line of business-animal furs. Traders diversified their fur cargoes with smaller quantities of sandalwood, pearls, ambergris, and trepang (Gibson, 1993: 132, 156-59). Early shipments of sandalwood were small, unofficial affairs. Hawaiian nobles often presented foreigners with ceremonial gifts such as "a large log of sandalwood" (Bloxam, 1925: 72). Other traders accepted 'iliahi in exchange for services rendered, and one received "passage money" in the form of "sandalwood to the value of $\$ 1,000$ " (Lydgate, 1916: 37). Most "shipments," however, originated in barter between individual Americans and Hawaiians. In acquiring "wood as handsome as mahogany," officers availed themselves of a traditional right to "personal trade" (Townsend, 1921: 28). These forms of sandalwood "cargo" occurred informally, and none warranted inclusion in official ship manifests, logs, or letters. 


\section{The market for sandalwood, 1804-1832}

Beginning in 1804, documentary evidence is adequate to construct an estimated price history for the American sandalwood trade in the Pacific. The disjointed character of the evidence, however, may explain why no historian has done so before now. The principal sources are incomplete in their treatment of sandalwood tonnages, prices, and earnings. As a result, they present some problems of reconciliation and calculation. Charles Gutzlaff published a table of American sandalwood imports at Canton, by weight, in A Sketch of Chinese History, Vol. II (1838). Hosea Ballou Morse included reference to sandalwood tonnage, price, and earnings data throughout five volumes of The Chronicles of the East India Company Trading to China, 1635-1834 (1926). Timothy Pitkin recorded a decade sandalwood imports at Canton, by gross earnings, in A Statistical View of the Commerce of the United States of America (1835). Other data is drawn from scattered ship journals, prices current, and other minor sources.

Gutzlaff presented data that approximates, but does not match, American imports as documented by the East India Company (E.I.C.). The discrepancies could represent trade secrets, smuggling, errors of documentation, or other unknowns. Gutzlaff did, however, supply a consistent record of imports from 1804-1832. For this reason, he provides the main source for import tonnages (Gutzlaff, 1838, II: Appendix IV). In comparison, Morse gave a fragmented account of sandalwood tonnages, with successive years of data available only for 1811-1812. Nevertheless. E.I.C. documents present a relatively consistent account of prices from 1817-1832. The documents also include gross earnings or profits realized in other years. Where this information is known in conjunction with tonnage, it becomes possible to estimate a sales price for sandalwood. As a result, Morse serves as the main source for sandalwood prices (Morse, 1929, III-IV). It is noteworthy that Pitkin's data diverges from Morse in some trading seasons (1817-1821) and matches in others (1822-1826). Considering this, I treat Pitkin as the authoritative source for American earnings during that decade (Pitkin, 1835: 304).

Some caveats are warranted. As demonstrated above, Cantonese merchants purchased multiple grades of sandalwood: first, second, third, and "Timore" (Columbia Papers I, 1787-1793). Most sources, however, record a single price-likely the premium grade. This assumption cannot be confirmed, making a clear differentiation between prices impossible. This essay generalizes upon an assumption that American captains trafficked in the same species and grade (pending ecological constraints). Unfortunately, the sources do not afford greater clarity. Americans also drew upon multiple supplies of sandalwood in the Pacific. The Hawaiian archipelago constituted the most lucrative supplier, but traders also acquired wood at Fiji, the Marquesas, "New Holland" and unnamed "islands of the Pacific." (Morse, 1929, III: 3-4, 104, 176, 215). The sources make little distinction between points of 
origin, but it is logical to presume that most shipments came from the Hawaiian Islands. The documented imports at Canton correspond to a period of declining production in Fiji and the Marquesas, leaving the Hawaiian Islands as the most likely supplier. (Shineberg, 1967: 7-8; Fontenoy, 1997: 11; Fichter, 2010: 219). Further research is warranted to illuminate these blind spots.

The construction of a price history also depends upon conversion between multiple currencies of the Pacific and Indian Ocean Worlds. Traders purchased Hawaiian sandalwood through barter in textiles, firearms, manufactured goods, and services, making the calculation of "purchase price" too abstract to be useful. Sandalwood transactions in China are recorded in a selection of six currencies (Chinese Taels, British Pounds, Spanish Dollars, Star Pagodas, Sikka Rupees, and Arcot Rupees). ${ }^{1}$ Cantonese exchange rates between the silver currencies (Taels, Pounds, Dollars) remained fixed throughout the sandalwood era, easing the calculation of transactions in China. Minor fluctuations occurred with respect to E.I.C. coinage (Pagodas and Rupees), which floated in rough proportion to the British Pound. For this reason, calculations are less reliable where evidence rests upon sandalwood purchased in India (Dubost, 1806: 183, 340; Milburn, 1813: 471; Morse, 1929, I: xxii).

\footnotetext{
1 Morse explained that E.I.C. accounts recognized a fixed exchange rate for sterling $[£ 1=3$ Taels]. Spanish Dollars also maintained a fixed rate $[\$ 1=0.72$ Taels] until 1815. Thereafter, the Spanish Dollar was "invoiced at the actual cost (c.i.f.) per oz.," although the E.IC. records a minor variation from the previous value only in 1818 [0.7199 Taels]. The stability of exchange rates eases our ability to estimate the sales price of sandalwood (Morse, 1929 II: xxii, II-III passim). The U.S. dollar also experienced minor fluctuations versus the Spanish Dollar. Timothy Pitkin appears to have treated them as interchangeable for purposes of his data (Pitkin, 1834: 304). Joseph Blunt gave the exchange rate for Indian currencies as: 1 Star Pagoda = 7s 51/4d [ $£ 0.3719]$; and 1 Arcot Rupee $=231 \frac{1}{4} \mathrm{~d}$ [£0.0968]. His numbers account for the introduction of standardized Rupees after 1818, but the earlier currencies remained in circulation and continued to appear in E.I.C. records (Blunt, 1837: 37172). Christopher Dubost provided a rate where 1 Sikka Rupee $=0.9309$ Arcot Rupees or approximately $21 \otimes d$ [£0.0902] (Dubost, 1806: 103).
} 
Table 1: Estimated Sales and Unit Price of American Sandalwood Imports at Canton, 1804-1832

\begin{tabular}{|c|c|c|c|c|c|c|}
\hline YEAR & $\begin{array}{l}\text { IMPORTS } \\
\text { (PICULS) } \\
\text { Gutzlaff }\end{array}$ & $\begin{array}{l}\text { SALES } \\
(\$) \\
\text { Pitkin }\end{array}$ & $\begin{array}{l}\text { SALES } \\
(\$) \\
\text { Morse }\end{array}$ & $\begin{array}{c}\text { SALES } \\
\text { (\$) } \\
\text { Reconstr. }\end{array}$ & $\begin{array}{c}\text { PRICE } \\
\text { (\$ / PICUL) } \\
\text { Gibson, et al. }\end{array}$ & $\begin{array}{c}\text { PRICE } \\
\text { (\$ / PICUL) } \\
\text { Reconstr. }\end{array}$ \\
\hline 1804 & 900 & & & & & \\
\hline 1805 & 1,600 & & & 44,445 & 27.78 & \\
\hline 1806 & 2,700 & & & 72,900 & 27.00 & \\
\hline 1807 & 2,000 & & & & & \\
\hline 1808 & 4,800 & & & & & \\
\hline 1809 & 1,815 & & & 34,032 & 18.75 & \\
\hline 1810 & 496 & & & 9,920 & 20.00 & \\
\hline 1811 & 11,261 & & & & & \\
\hline 1812 & 19,036 & & & 394,045 & & $20.70^{*}$ \\
\hline 1813 & 1,100 & & & 20,548 & & $18.68^{*}$ \\
\hline 1814 & & & & & & $22.97^{*}$ \\
\hline 1815 & 2,500 & & & & & \\
\hline 1816 & 7,400 & & & & & \\
\hline 1817 & 15,825 & 174,075 & 166,200 & & & 11.00 \\
\hline 1818 & 14,874 & 91,368 & & & & 6.14 \\
\hline 1819 & 10,073 & 82,228 & 101,228 & & & 8.16 \\
\hline 1820 & 6,005 & 67,133 & & & & 11.18 \\
\hline 1821 & 26,822 & 268,220 & 269,320 & & & 10.00 \\
\hline 1822 & 20,653 & 139,408 & 139,408 & & 10.00 & 6.75 \\
\hline 1823 & 8,404 & 67,232 & 67,232 & & 8.50 & 8.00 \\
\hline 1824 & 7,438 & 66,942 & 66,942 & & & 9.00 \\
\hline 1825 & 3,097 & 32,518 & 32,518 & & & 10.50 \\
\hline 1826 & 6,680 & 83,500 & 83,500 & & & 12.50 \\
\hline 1827 & 13,265 & & 211,070 & & 11.50 & 15.91 \\
\hline 1828 & 18,206 & & 127,442 & & 7.00 & 7.00 \\
\hline 1829 & 10,807 & & 43,228 & & 4.75 & 4.00 \\
\hline 1830 & 9,750 & & 39,000 & & 4.25 & 4.00 \\
\hline 1831 & 1,400 & & 7,000 & & & 5.00 \\
\hline 1832 & 5,600 & & 28,000 & & & 5.00 \\
\hline
\end{tabular}

All values given in Spanish Dollars. Import volume drawn from Gutzlaff. Italics indicate total sales calculated from a combination of import volume (piculs) and sale value (\$/picul). Price calculations are made with a first preference for sale values given in Pitkin (1835), which may represent the most 
accurate picture of U.S. imports during the decade 1817-1826. Second preference is given to sale values provided in Morse (1929), and third preference given to sales reconstructed from ancillary data in Morse. Prices marked with an asterisk $\left(^{*}\right)$ are derived entirely from data in Morse. See exchange rates cited above.

Sources: GIBSON, 1992: 256; GUTZLAFF, 1838, II: appendix IV; MILBURN, 1823, II: 491; MORSE 1929, III: 3-4, 104, 158, 176, 205-06, 228, 307, 328, 330-31, 344, 346, 368-69; MORSE, 1929, IV: 4, 20, 67, 84, 88, 99, 118, 121, 127, 139, 143, 158, 181, 191, 248, 271, 339.; New York Herald (25 June 1806), 2; PITKIN, $1835:$ 304; ROQUEFUEIL, 1823: 52-53.

\section{Obstacles to trade, 1791-1814}

American merchant-captains experimented with sandalwood in both formal and informal ways from 1791-1814, but their experience did not immediately result in reliable trade. What explains their failure to capitalize on a promising new commodity? With the possible exception of Hawaiian political upheavals in 1795, there was no significant obstacle to the acquisition of 'iliahi. Sandalwood was widely available in the early years. A growing - although sensitive-market waited at Canton. One explanation is that the Pacific sandalwood trade came of age during a time of geopolitical instability.

The beginning of the sandalwood trade corresponds to a period of intermittent warfare between rival kingdoms administered from the islands of Hawaii and Maui. The most powerful warlords funded the modernization of their forces through the sale of sandalwood. Vancouver observed that Kamehameha sold Hawaiian goods at the cost of "arms and ammunition." The importation of firearms, he noted, "has produced in every chief of consequence an inordinate thirst for power" and "great avidity for these destructive engines." (Vancouver, 1798, I: 18687). Sandalwood also purchased heavier weapons. One visitor later reported that "there were from 600 to 700 pieces of artillery upon the several islands" (Bloxam, 1824: 34). Kamehameha financed an ambitious program of naval armament, featuring shipyards and a blacksmith forge, in part with exports of sandalwood (Townsend, 1921: 23-34). The fiscal demands of unification and state-formation prompted nobles to harvest enormous quantities of 'iliahi. The islands exported an estimated 6.1 million pounds of wood, worth perhaps $\$ 576,000$, during the first decade of documented exports (1804-1813). In short, sandalwood was available and profitable to the producers. Challenges to the development of a reliable trade did not originate on the supply side.

Instead, Americans encountered demand-side obstacles to their development of a sandalwood trade at Canton. Competition from preexisting business was a significant hindrance. Chinese consumers had a longstanding relationship 
with tanxiang, and they obtained aromatic wood through a succession of middlemen prior to the arrival of Americans. Sandalwood appears in Chinese documents as early as 454 , and Cambodian vessels made deliveries throughout the following century (Schafer, 1957: 130; Wang, 1958: 53). Thereafter, Arabian and Malay captains imported sandalwood along with resins such as frankincense, aloes, and camphor (Morley, 1949: 145, 164; Villiers, 2001: 27-28). Demand for tropical aromatics boomed in parallel with globalization during the Song, Yuan, and Ming Dynasties (Ptak, 2006: 484-85; Soon, 2001: 146). Cantonese captains sought tanxiang in distant Sumatra, India, and perhaps Africa (Sen, 2006: 424). Europeans dominated the trade in aromatics after 1750, and they regarded sandalwood as a "cornerstone" of the China Trade (Morse, 1922: 251). The incomplete nature of the evidence makes it impossible to know the overall scale of tanxiang imports at Canton, but Americans clearly entered an established market.

The delicate balance of supply and demand also complicated American trade. Prior to U.S. involvement, Chinese demand for tanxiang rested at an equilibrium price of around \$20-24 per picul (133\ pounds) and prices occasionally spiked as high as $\$ 31$ (Morse, 1929, II: 70). Beginning in 1804, American traders flooded the market, with predictable results. Over the subsequent decade, U.S. vessels imported 45,708 piculs of sandalwood, representing fully $52 \%$ of all documented imports and doubling the overall supply. The glut of tanxiang was particularly noticeable from 1811-1812, when Americans imported 4,000,000 pounds of wood-three times the reported E.I.C. volume. In 1812, the outbreak of war between the United States and Great Britain prevented the market from reaching a terminal state of saturation. The following year, prices rebounded by $23 \%$ when "the war kept American ships away from Canton, or at any rate much diminished their number" (Morse, 1929, III: 191). In short, conflict sustained the delicate market for aromatic wood. 
Table 2: Estimated U.S., East India Company, and Private British imports of Sandalwood at Canton (Piculs), 1804-1832

\begin{tabular}{|c|c|c|c|c|c|}
\hline YEAR & $\begin{array}{c}\text { U.S. } \\
\text { (PICULS) }\end{array}$ & $\begin{array}{c}\text { E.I.C. } \\
\text { (PICULS) }\end{array}$ & $\begin{array}{l}\text { PRIVATE } \\
\text { (PICULS) }\end{array}$ & $\begin{array}{l}\text { TOTAL } \\
\text { (PICULS) }\end{array}$ & $\begin{array}{c}\text { U.S. SHARE } \\
(\%)\end{array}$ \\
\hline 1804 & 900 & 841 & & 1,741 & 51.69 \\
\hline 1805 & 1,600 & & & 1,600 & \\
\hline 1806 & 2,700 & & & 2,700 & \\
\hline 1807 & 2,000 & & & 2,000 & \\
\hline 1808 & 4,800 & & & 4,800 & \\
\hline 1809 & 1,815 & 9,650 & & 11,465 & 15.83 \\
\hline 1810 & 496 & & 7,588 & 8,084 & 6.14 \\
\hline 1811 & 11,261 & 4,067 & & 15,328 & 73.47 \\
\hline 1812 & 19,036 & 5,559 & & 24,595 & 77.40 \\
\hline 1813 & 1,100 & 15,108 & & 16,208 & 6.79 \\
\hline 1814 & & 7,162 & & 7,162 & \\
\hline 1815 & 2,500 & 12,430 & & 14,930 & 16.74 \\
\hline 1816 & 7,400 & & & 7,400 & \\
\hline 1817 & 15,825 & & & 15,825 & \\
\hline 1818 & 14,874 & & & 14,874 & \\
\hline 1819 & 10,073 & & & 10,073 & \\
\hline 1820 & 6,005 & & & 6,005 & \\
\hline 1821 & 26,822 & & 6,667 & 33,489 & 80.09 \\
\hline 1822 & 20,653 & & & 20,653 & \\
\hline 1823 & 8,404 & & & 8,404 & \\
\hline 1824 & 7,438 & & & 7,438 & \\
\hline 1825 & 3,097 & 574 & 8,011 & 11,682 & 26.51 \\
\hline 1826 & 6,680 & 1,793 & & 8,473 & 78.84 \\
\hline 1827 & 13,265 & & & 13,265 & \\
\hline 1828 & 18,206 & & 9,892 & 28,098 & 64.79 \\
\hline 1829 & 10,807 & & 16,697 & 27,504 & 39.29 \\
\hline 1830 & 9,750 & & 11,100 & 20,850 & 46.76 \\
\hline 1831 & 1,400 & & 6,338 & 7,738 & 18.09 \\
\hline 1832 & 5,600 & & 2,075 & 7,675 & 72.96 \\
\hline Total & 234,507 & 57,184 & 68,368 & 360,059 & 45.03 \\
\hline
\end{tabular}

This chart does not present U.S. percentage share for seasons when company and private tonnages are unknown (either due to absence of imports or omission).

Sources: GUTZLAFF, 1838, III: appendix IV; MORSE ,1929, III: 3-4, 104, 158, 176, 205-06, 228, 307, 328, 33031, 344, 346, 368-69; IV: 4, 20, 67, 84, 88, 99, 118, 121, 127, 139, 143, 158, 181, 191, 248, $271,339$. 
Recent scholarship reflects a growing consensus that protracted warfare from 1793 to 1815 promoted the economic growth of neutral or "weak" nations such as the United States. One argument holds that neutral states experienced economic growth as suppliers and markets to more powerful belligerents. In this respect, the American China Trade represented part of a larger expansion of trade to nations other than Great Britain and France (Land et al., 2018: 29-30, 42). James Fichter emphasizes that U.S. traders entered the commercial breach in a manner that presented the East India Company with "a new and vigorous competitor in Asia" (Fichter, 2010: 4). The American sandalwood trade demonstrates a variation on the theme. U.S. traders certainly benefitted from access to producers on "neutral" islands, but political tensions and warfare often hindered their ability to deliver sandalwood to Canton.

Geopolitical interruptions contributed to the fitful development of the sandalwood trade. Some obstacles resulted from the Qing Imperial practice of using commerce as a political weapon. In 1791, imperial officials extended an embargo against Russian merchants to include the maritime fur trade in general. In 1810, Cantonese officials threatened another embargo over issues of unpaid duties, smuggling, and an ongoing murder investigation. Chinese pirates also attacked, captured, and ransomed foreign ships with impunity (Fu, 1966: 319-20, 360). European merchantmen soon sailed under escort, but U.S. warships were too few to protect to sandalwood traders in the Pacific (Morse, 1929, III: 116). Other interruptions originated in the French Revolutionary and Napoleonic Wars. In 1797, Bostonian merchant Thomas Handasyd Perkins complained of the "vile conduct of the Republican Cruisers" and feared that "privateers may be troublesome in the Straights of Sunda next spring." Thereafter, Perkins reaffirmed his determination "to concentrate our property in the Canton trade," but his plans faltered during Jefferson's notorious embargo of 1807-1809 (Perkins, 1944: 54, 64, 98; Morse, 1929, III: 77).

American efforts to establish the sandalwood trade became doubly difficult when European affairs intruded upon the Canton System. In 1808, the British occupation of Portuguese Macao-still Qing territory-brought Atlantic warfare to the shores of China. In response, the emperor punished "the barbarian soldiers of England" by threatening a blockade of foreign communications and supplies (Fu, 1966: 371-73). From 1808-10, American sandalwood imports plummeted from 4,800 piculs to 496 piculs, a $90 \%$ decline. The eruption of the Anglo-American War, in 1812, represented the culmination of two decades of uncertain trade. Cantonese officials reported that the nations had begun "plundering each other's goods and money" in the South China Sea. Qing authorities insisted that the belligerents should "obey and respect the prohibitions of the Celestial Empire" and demanded that British privateers not attempt "to obtain revenge on the Americans here" (Fu, 1966: 371-73). By and large, U.S. traders elected to remain in port, in the islands, or to sail homeward during the conflict (Howay, 1973: 92-102). American sandalwood 
imports collapsed in wartime, falling from the robust volume of 19,036 piculs in 1812 to nothing in 1814 . Overall, the sandalwood trade faced interruptions from embargos, piracy, or armed conflict in 13 of 23 seasons from 1791-1814.

\section{The decline and fall of sandalwood, 1821-32}

In 1815, following the war, American sandalwood traders returned to Canton and again saturated the market. From this point onward, no serious interruptions hindered the development of a reliable trade in 'iliahi. Indeed, American traders dominated the Hawaii-China circuit in increasing numbers after 1815. One diplomat estimated that at least five U.S. vessels, averaging 200-300 tons burden, traded sandalwood each year (Bland, 1834: 311). Stability, however, brought new problems. The American trade that seemed so promising in the 1790s, and appeared within reach after 1804, began a terminal slide in 1822. In short, sandalwood became a victim of its own success.

Scholars long ago identified some general reasons for the decline and fall of sandalwood, but their explanations lack chronological and causal nuance. Mark Merlin, a botanist, claimed that "the price fell in the later 1820's as a result of poor quality" (Merlin and VanRavenswaay, 1990: 50). In fact, prices began their dramatic slide in 1817. Paul Fontenoy explained that "the assault on the sandalwood forests was so devastating that the trade effectively ceased by 1829 due to over-cutting." The impact of intensive harvesting cannot be denied, but this explanation neglects the prohibitive cost of harvesting alternative species of Santalum. Fontenoy identifies the competitive role of Fijian and Marquesan sandalwood, from 1804-17, but he overlooks the growth of Melanesian production in the 1820s (Fontenoy, 1997: 11-12). The remainder of this essay considers a constellation of factors in the decline of 'iliahi.

The period from 1817-21 represented a sweet spot in the sandalwood trade. Chinese demand for sandalwood was underserved from 1814-16, when imports totaled only $53 \%$ of the previous three-year period (1811-13). Americans returned with ample cargos - more than 9.8 million pounds! — from 1817-21. The glut of sandalwood drove sale prices downward, but not catastrophically. In fact, tanxiang settled at a plateau around $\$ 10$ by 1817 . The most profitable year for American traders, 1821 , saw peak imports of 1,788 tons and earnings of $\$ 269,000$. During this intermediate period, then, trade probably approached an equilibrium of supply and demand. The American sandalwood trade would never again be so robust or profitable. In 1822, the market for tanxiang was so near saturation that the import of 20,653 piculs (1,377 tons), triggered a collapse in demand. Sales prices fell $33 \%$, from roughly $\$ 10$ to $\$ 6.75$ per picul, in a single year. Prices continued to slide throughout the decade (despite a few healthy seasons), ultimately reaching 
the abysmal rate of $\$ 5$ per picul by 1829 . Three good seasons, from $1825-27$, are probably the reason that traders did not abandon sandalwood sooner.

The decade 1822-32 witnessed the long death of the American sandalwood trade, but the decline of 'iliahi represented the confluence of several factors. The economics of deforestation was probably a consideration. We cannot be certain which species early traders collected, as scientific classification began later, in 1819 (Merlin and VanRavenswaay, 1990: 46). Two candidates grew at the documented sites of early trading. Santalum ellipticum, a shrub known as "coastal sandalwood," spanned the archipelago at altitudes below 1400 meters. Santalum paniculatum, a tree, grows exclusively on Hawaii at altitudes below 1390 meters (Stemmermann, 1980: 49-52). Species native to higher elevations became important only after the depopulation of more convenient lowland varieties. In this respect, sandalwood corresponds to the larger pattern of exploitation and collapse of other biological resources in the region, such as sea otters, seals, and whales (Gibson, 1992: 175-76; Busch, 1985: 191-220; Igler, 2013: 99-127).

Deforestation appears to have occurred in a relatively short period of timeone that corresponds to the era of reliable and moderate profits between 1817 and 1821. Chinese demand ensured the cutting of sandalwood at an unsustainable pace. In 1817, James Hunnewell identified sandalwood as the "chief article" of business and a commodity so plentiful that it constituted "the standard coin" of the islands (Hunnewell, 1895: 16). King Kamehameha compelled commoners to harvest thousands of tons of 'iliahi through corvée labor. In 1822, Gilbert Mathison explained that "gratuitous" labor had reduced the cost of production to "absolutely nothing." Nonetheless, he concluded that "iliahi was "not likely to become exhausted for a considerable period of time" and observed that "large forests still remain untouched" on Hawaii (Mathison, 1825: 450-51, 457-58). Mathison underestimated the pace of deforestation. Santalum reaches commercial maturity only after a century of growth (USDA, 1990: 4). William Ellis observed large parties of "three or four hundred people, returning with sandal wood, which they had been cutting in the mountains" (Ellis, 1917: 227). Natural replenishment could not keep up with harvests on such a scale, and some chiefs began to withhold supplies (Hammatt, 1999: 26).

Scarcity fueled a transition toward less accessible species of 'iliahi and a probable spike in the cost of production. Santalum freycinetianum grows throughout the islands at elevations up to 1150 meters, although the best specimens prefer an altitude of $600+$ meters. This species, which achieves a height of 80 feet and a diameter of 3 feet, was commercially desirable for its high output of aromatic heartwood (Merlin and VanRavenswaay, 1990: 46). But commercial exploitation decimated the coastal forests. By 1824, Andrew Bloxam remarked that he "could not find one sandalwood tree" in lowland Oahu because "all had probably been cut down about here for the purpose of barter" (Bloxam, 1925: 38). Santalum 
haleakale, the remaining species, grows at higher elevations of 1800-2590 meters (Merlin and VanRavenswaay, 1990: 46). Indeed, Jacobus Boelen reported in 1828 that sandalwood "already... had to be fetched from the most inaccessible parts of the mountains" (Boelen, 1988: 76). The higher investment in labor, time, and transport undoubtedly increased the production cost, as well as purchase price. In a climate of shrinking profits, many American traders looked to alternative branches of commerce in goods, provisions, and shipping-for-hire.

Scarcity, competition, and declining profits contributed to the collapse of the American trade in Hawaiian sandalwood. The inaccessibility of mature 'iliahi created conditions of scarcity, such that "old fashioned good wood" became rare and in some places "not a stick of wood" could be found. Meanwhile, prices rose for specimens considered "of rather inferior quality" (Hammatt, 1999: 32, 42). Indian production continued to exert competitive pressure, and the exploitation of mature forests had begun in Melanesia. Ships laden with hundreds of tons of sandalwood became commonplace sights at Guam, New Guinea, and the Isle of Pines. In Canton, tanxiang sold at unprofitable rates. Some captains imported hundreds of tonsand realized only a few dozen dollars (Shineberg, 1967: 9-13, 29-46, 138). In short, American traders found themselves trapped between a widening pair of price scissors in the 1820s. In 1823, Charles Hammatt was exasperated that the brig Arab "sold their wood at $\$ 5 / 4$ " at Canton. He lamented that "I thought it was bad enough when we expected to get $\$ 10$ for our wood, but losing 50 percent on that, will just about finish it." (Hammatt, 1999: 32-33). Within a decade, his fellow traders followed suit.

\section{Primary sources}

BLAND, Theodorick (1834), "Report of Theodorick Bland, on the Condition of South America [1819]," in American State Papers, Vol. IV, edited by Walter Lowrie and Walter S. Franklin, Washington, Gales and Seaton, 270-323.

BLOXAM, Andrew (1925), Diary of Andrew Bloxham, Naturalist of the "Blonde" on Her Trip from England to the Hawaiian Islands, 1824-25, Honolulu, Bernice P. Bishop Museum.

BLUNT, Joseph (1837), The Shipmaster's Assistant and Commercial Digest: Containing Information Useful to Merchants, Owners, and Masters of Ships, New York, E. \& G.W. Blunt.

BOELEN, Jacobus (1988), A Merchant's Perspective: Captain Jacobus Boelen's Narrative of His Visit to Hawai'i in 1828, Honolulu, Hawaiian Historical Society.

BOIT, John (1981), Log of the Union: John Boit's Remarkable Voyage to the Northwest Coast and Around the World, 1794-1796, edited by Edmund Hayes, Portland, Oregon Historical Society.

DELANO, Amasa (1817), Narrative of Voyages and Travels in the Northern and Southern Hemisphere: Comprising Three Voyages Round the World; Together with a Voyage of Survey and Discovery in the Pacific Ocean and Oriental Islands, Boston, E.G. House.

DUBOST, Christopher (1806), The Elements of Commerce, 2 vols., London, Knight and Compton.

ELLIS, William (1917), Narrative of a Tour through Hawaii, or Owhybee; with Remarks on the History Traditions, Manners, Customs, and Language of the Inhabitants of the Sandwich Islands, Honolulu, Honolulu Gazette Co., Ltd. 
GUTZLAFF, Charles (1834), A Sketch of Chinese History, Ancient and Modern: Comprising a Retrospect of the Foreign Intercourse and Trade with China, 2 vols., London, Smith, Elder and Company.

HAMMATT, Charles H. (1999), Ships, Furs, and Sandalwood: A Yankee Trader in Hawai'i, 18231825 , edited by Sandra Wagner-Wright, Honolulu, University of Hawaii Press.

HUNNEWELL, James Jr. (ed.) (1895), "Honolulu in 1817 and 1818, by James Hunnewell", Papers of the Hawaiian Historical Society, 8, 3-23.

INGRAHAM, Joseph (1971), Voyage of the Brigantine "Hope" on a Voyage to the Northwest Coast of North America, 1790-1792, edited by Mark D. Kaplanoff, Barre, MA, Imprint Society.

KALAKUA, David (1888), The Legends and Myths of Hawaii: The Fables and Folk-Lore of a Strange People, edited by R.M. Daggett, New York, Charles L. Webster \& Company.

KUYKENDALL, Ralph S. (1934), “Early Hawaiian Commercial Development”, Pacific Historical Review, 3, 365-85.

LEDYARD, John (1783), A Journal of Captain Cook's Last Voyage to the Pacific Ocean and in Quest of a North-West Passage between Asia \& America, Performed in the Years 1776, 1777, 1778, and 1779, Hartford, Nathaniel Patten.

MILBURN, William (1813), Oriental Commerce; Containing a Geographical Description of the Principal Places in the East Indies, China, and Japan, Including the Coasting or Country Trade from Port to Port, 2 vols., London, Black, Parry, \& Co.

MALO, David (1903), Hawaiian Antiquities (Moolelo Hawaii), translated by N.B. Emerson, Honolulu, Hawaiian Gazette Co.

MATHISON, Gilbert Farquhar (1825), Narrative of a Visit to Brazil, Chile, Peru, and the Sandwich Islands, During the Years 1821 and 1822, London, Charles Knight.

New York Herald (New York, New York), 25 June 1806, 2.

PERKINS, Thomas Handasyd (1856), Memoir of Thomas Handasyd Perkins: Containing Extracts from his Diaries and Letters, edited by Thomas G. Gray, Boston, Little, Brown, and Company.

PERKINS, Thomas Handasyd (1944), Extracts from Letter Books of J. and T.H. Perkins et al., 1786 1838 , edited by James Elliot Cabot, Boston Athenaeum, Typescript.

PITKIN, Timothy (1835), A Statistical View of the Commerce of the United States of America, New Haven, Durrie \& Peck.

QUIMPER, Manuel (1952), “The Hawaiian Journal of Manuel Quimper”, edited by William Harvey Minson, Jr., MA Thesis, Honolulu, University of Hawaii.

ROQUEFEUIL, M. Camille de (1823), Voyage Round the World Between the Years 1816-1819, London, Sire Richard Phillips and Co.

TOWNSEND, Ebenezer, Jr. (1921), "Extract from the Diary of Ebenezer Townsend, Jr., Supercargo of the Sealing Ship 'Neptune' on Her Voyage to the South Pacific and Canton", Hawaiian Historical Society Reprints, 4, 1-33.

VANCOUVER, George (1798), A Voyage of Discovery to the North Pacific Ocean and Round the World, 3 vols., London, G.G. and J. Robinson and J. Edwards.

\section{Secondary sources}

BRADLEY, Harold Whitman (1939), "The Hawaiian Islands and the Pacific Fur Trade, 17851813", The Pacific Northwest Quarterly, 39, 275-299.

BUSCH, Briton Cooper (1985), The War Against the Seals: A History of the North American Seal Fishery, Montreal, McGill-Queen's University Press.

Business Historical Society (1929), "China and the Foreign Devils", Bulletin of the Business Historical Society, 3, 9-19. 
DRECHSEL, Emanuel J. (2014), Language Contact in the Early Colonial Pacific: Maritime Polynesian Pidgin before Pidgin English, Cambridge, Cambridge University Press.

ELMORE, H. M. (1802), The British Mariner's Directory and Guide to the Trade and Navigation of the Indian and Chinese Seas, London, T. Bensley.

FELGELSON, Joseph (1990), "Sandalwood-the Myth and the Reality," U.S. Department of Agriculture, Forest Service, Pacific Southwest Research Station", General Technical Report PSW-122. Proceedings of the Symposium on Sandalwood in the Pacific, April 9-11, 1990, Honolulu, USDA, 39-42.

FICHTER, James (2010), So Great a Proffit: How the East Indies Trade Transformed Anglo-American Capitalism, Cambridge MA, Harvard University Press.

FONTENOY, Paul E. (1997), "Ginseng, Otter Skins, and Sandalwood: The Conundrum of the China Trade", The Northern Mariner/Le Marin du nord, 7, 1-16.

FU, Lo-shu (ed.) (1966), A Documentary Chronicle of Sino-Western Relations, 16441820, Tucson, University of Arizona Press.

GIBSON, Arrell Morgan, WHITEHEAD, John S. (1993), Yankees in Paradise: The Pacific Basin Frontier, Albuquerque, University of New Mexico Press.

GIBSON, James R. (1992), Otter Skins, Boston Ships, and China Goods: The Maritime Fur Trade of the Northwest Coast, 1785-1841, Montreal, McGill-Queens University Press.

HOWAY, Frederic W. (1928), "The Hawaiian Islands: Early Relations with the Pacific" in Albert Pierce Taylor and Ralph S. Kuykendall (eds.), Papers Read During the Captain Cook Sesquicentennial Celebration, Honolulu, August 17, 1928, Honolulu, Captain Cook Sesquicentennial Commission and Archives of Hawaii Commission, 11-38.

HOWAY, Frederic W. (ed.) (1941), Voyages of the Columbia to the Northwest Coast, 1787 1790 and 1790-1793, Boston, Massachusetts Historical Society.

HOWAY, Frederic W., PIERCE, Richard A. (eds.) (1973), A List of Trading Vessels in the Maritime Fur Trade, 1785-1825, Kingston ON, The Limestone Press.

IGLER, David (2013), The Great Ocean: Pacific Worlds from Captain Cook to the Gold Rush, New York, Oxford University Press.

KAMAKAU, Samuel M. (1961), Ruling Chiefs of Hawaii, Honolulu, Kamehameha Schools.

KUYKENDALL, Ralph S. (1934), "Early Hawaiian Commercial Development", Pacific Historical Review, 3, 365-385.

LAND, Jeremy, ELORANTA, Jari, MOREIRA, Maria Cristina (2018), "Early American Trade and Neutrality: 1783-1860", in Jari Eloranta, Eric Golson, Peter Hedburg, Maria Cristina Moreira (eds.), Small and Medium Powers in Global History: Trade, Conflicts, and Neutrality from the $18^{\text {th }}$ to $20^{\text {th }}$ Centuries, New York, Routledge, 461-479.

LITTLE, Elbert L., Jr., SKOLMEN, Roger G. (1989), Common Forest Trees of Hawaii (Native and Introduced), Washington, D.C., USDA, Forest Service.

LYDGATE, John M. (1916), "Ka-umu-alii, The Last King of Kauai", Report of the Hawaiian Historical Society, 24, 21-43.

MERLIN, Mark, VANRAVENSWAAY, Dan (1990), "The History of Human Impact on the Genus Santalum in Hawai'i," U.S. Department of Agriculture, Forest Service, Pacific Southwest Research Station", General Technical Report PSW-122. Proceedings of the Symposium on Sandalwood in the Pacific, April 9-11, Honolulu, USDA, 46-60.

MORISON, Samuel Elliot (1920-21), "Boston Traders in the Hawaiian Islands, 1789-1823", Proceedings of the Massachusetts Historical Society, Third Series, 54, 9-47.

MORLEY, J. A. E. (1949), "The Arabs and the Eastern Trade", Journal of the Malayan Branch of the Royal Asiatic Society, 22, 143-176. 
MORSE, Hosea Ballou (1926), The Chronicles of the East India Company Trading to China, 1635-1834, 5 Vols., Oxford, The Clarendon Press.

MORSE, Hosea Ballou (1922), "The Provision of Funds for the East India Company's Trade at Canton during the Eighteenth Century", The Journal of the Royal Asiatic Society of Great Britain and Ireland, 2, 227-255.

NOKES, Richard (1991), Columbia's River: The Voyages of Robert Gray, 1787-1793, Tacoma WA, Washington State Historical Society.

PTAK, Roderich (2006), "Trade Between Macau and Southeast Asia in Ming Times: A Survey", Monumenta Serica, 54, 465-489.

SCHAFER, Edward H. (1957), "Rosewood, Dragon's Blood, and Lac", Journal of the American Oriental Society, 77, 129-136.

SUBASINGHE, Upul (2013), "Sandalwood Research: A Global Perspective", Journal of Tropical Forestry and Environment, 3, 1-8.

ST. JOHN, Harold, (1947) "The History, Present Distribution, and Abundance of Sandalwood on Oahu, Hawaiian Islands: Hawaiian Plant Studies 14", Pacific Science, 1, 5-20.

STEMMERMANN, Lani (1980) "Observations on the Genus Santalum (Santalaceae) in Hawai'i', Pacific Science, 34, 41-54.

SOON, Derek Heng Thiam (2001), "The Trade in Lakawood Products Between South China and the Malay World from the Twelfth to Fifteenth Centuries AD", Journal of Southeast Asian Studies, 32, 133-149.

THRUM, Thomas G. (1904), "The Sandalwood Trade of Early Hawaii", Thrum's Hawaiian Almanac and Annual for 1905, Honolulu, Thomas Thrum.

VILLIERS, John (2001), "Great Plenty of Almug Trees: The Trade in Southeast Asian Aromatic Woods in the Indian Ocean and China, 500 BC-AD 1500", The Great Circle, 23, 24-43.

WANG, Gungwu (1958), "The Nanhai Trade: A Study of the Early History of Chinese Trade in the South China Sea", Journal of the Malayan Branch of the Royal Asiatic Society, 31, 1-135. 